University of Louisville

ThinkIR: The University of Louisville's Institutional Repository

\title{
Identification and expression analysis of sugar transporters in microbotryum violaceum.
}

Jared Morris Andrews

University of Louisville

Follow this and additional works at: https://ir.library.louisville.edu/honors

Part of the Biology Commons, and the Plant Sciences Commons

\section{Recommended Citation}

Andrews, Jared Morris, "Identification and expression analysis of sugar transporters in microbotryum violaceum." (2014). College of Arts \& Sciences Senior Honors Theses. Paper 43.

http://doi.org/10.18297/honors/43

This Senior Honors Thesis is brought to you for free and open access by the College of Arts \& Sciences at ThinkIR: The University of Louisville's Institutional Repository. It has been accepted for inclusion in College of Arts \& Sciences Senior Honors Theses by an authorized administrator of ThinkIR: The University of Louisville's Institutional Repository. This title appears here courtesy of the author, who has retained all other copyrights. For more information, please contact thinkir@louisville.edu. 
Identification and Expression Analysis of Sugar Transporters in Microbotryum violaceum

\section{By}

Jared Morris Andrews

Submitted in partial fulfillment of the requirements for Graduation summa cum laude and

for Graduation with Honors from the Department of Biology

University of Louisville

March 2014 


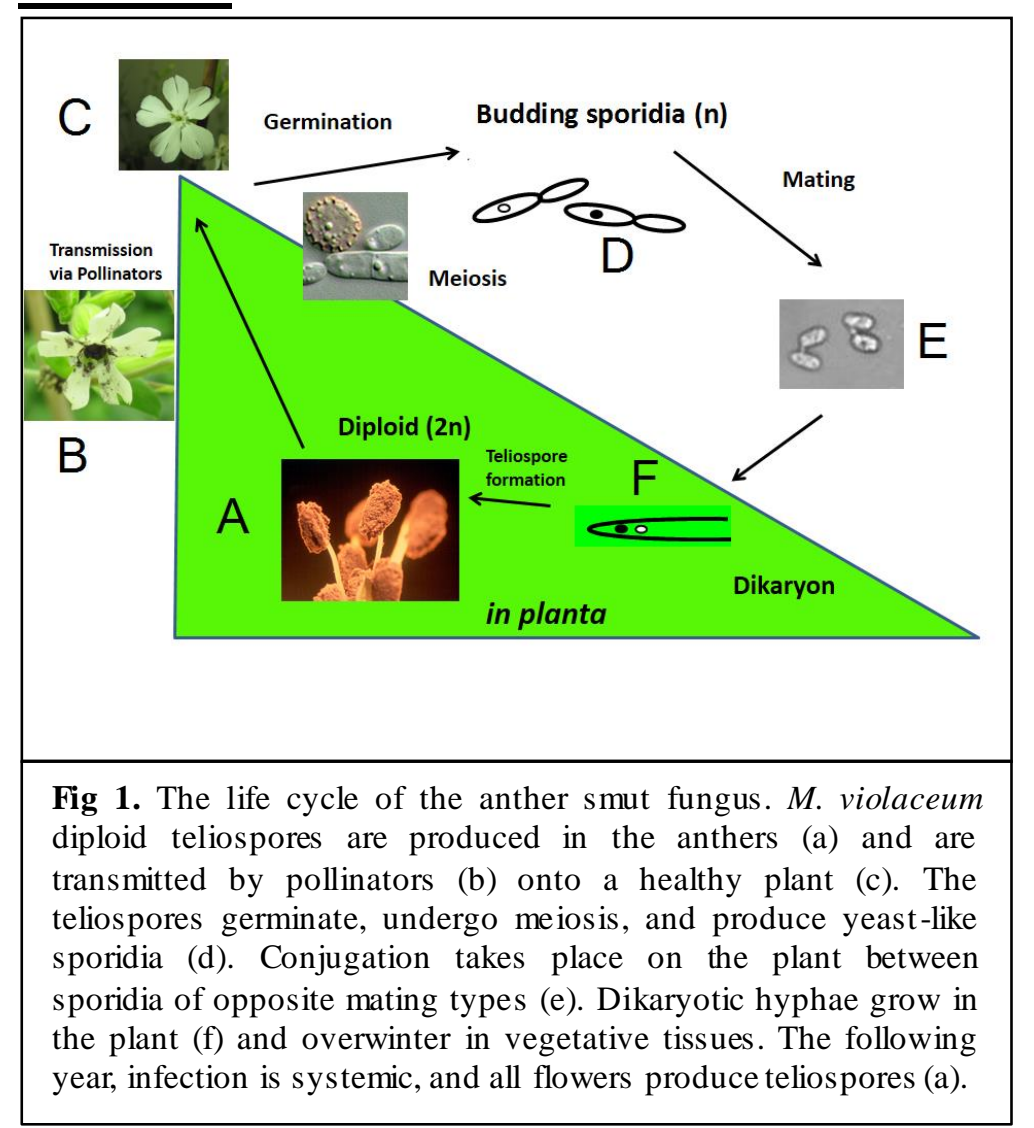

Microbotryum violaceum is a

heterobasidiomycete fungal pathogen

that infects Silene latifolia, a

dioecious wildflower species. $M$.

violaceum is an obligate biotroph,

meaning that it requires the host plant

living tissue in order to grow; as such,

it must infect a host to complete its

life cycle and must do so without

killing the host. Infection sterilizes the

plant, and in male plants, replaces the

pollen grains with teliospores (Fig 1).

In female plants, the fungus invokes the growth of stamen and anthers on which to place its

teliospores. In either male or female (pseudomale) flowers, the teliospores may then be spread to

uninfected plants by insect pollinators [1]. Haploid cells of $M$. violaceum contain one of two mating

types, A1 or A2, and cells of opposite mating type must mate to produce the form of the fungus

necessary for infection to occur.

Most model systems for fungal host/pathogen interactions are within agricultural systems

[2]. M. violaceum provides an opportunity to study host/pathogen interactions in a "wild", less

manipulated setting, where host populations may not be as genetically similar as those for

agricultural pathogens $[1,2]$. $M$. violaceum can also serve as a model for the study of host shifts by

infectious diseases [2]. This system also allows for further study of genes that may be necessary for pathogenicity [8]. Though a number of pathogenicity genes have already been discovered for

phytopathogenic fungi $[9,10]$, those required for pathogenicity of $M$. violaceum are still unknown. 


\section{Background}

A draft genome sequence at $18 \mathrm{x}$ coverage was produced for a haploid strain derived from meiosis of teliospores isolated from the host Silene latifolia. The draft sequence is currently in the process of annotation and is publicly available through a website from the Broad Institute of MIT and Harvard (http//www.broadinstitute.org/annotation/genome/Microbotryum_violaceum/ MultiHome.html). Using Illumina Next Gen sequencing, deep transcriptome information is being generated about a variety of stages in the lifecycle of the fungus, with particular emphasis on the late stages of infection, when teliosporogenesis occurs. This means that "global" gene expression information is being generated by this method for essentially all predicted $M$. violaceum genes during each of the stages being examined.

As presented in recent publications, sugar transporters in fungi have been shown to affect fungal virulence in plants, particularly in the case of biotrophic fungi such as Ustilago maydis and several species of rust fungi $[11,12,17,18]$. Specifically, the $\operatorname{srt} 1$ gene in $U$. maydis was found to code for a high-affinity, sucrose-specific transporter that likely provides advantages for the acquisition of carbon after the infection of host tissue as well as helping to prevent plant defense mechanisms from being induced. Bringing sucrose into the fungal cell rather than breaking sucrose down outside of the cell and transporting the resulting simple sugars into the cell is less likely to be recognized by the plant [18]. The hxtl gene in the rust fungus Uromyces fabae codes for a hexose transporter that may fulfill a similar role, as it is upregulated in rust haustoria, an important fungal organ during infection [17].

The importance of sugar transporters for pathogenicity of $M$. violaceum is unknown. Thus, identifying and determining possible roles in pathogenicity of these sugar transporters is of interest. Such work may give insight both as to how the fungus initially infects its host and how this infection is maintained in order for the fungus to complete its life cycle [9]. 


\section{$\underline{\text { Methods }}$}

Initial Bioinformatic Analyses and Target Gene Selection

Potential sugar transporter genes of Microbotryum violaceum were identified by comparing the srt 1 and hxtl genes from $U$. maydis and $U$.fabae, respectively, with the $M$. violaceum genome and proteome through the use of BLASTP and BLASTN (Protein/Nucleotide Basic Local Alignment Search Tool). BLAST is a readily accessible online bioinformatics tool that compares DNA, RNA, or amino acid sequences to databases of similar sequences, such as genomes, transcriptomes, and proteomes. Genes that have some degree of similarity to the entered sequences are listed as results. To assure that potential hits from BLAST are likely sugar transporters, other data were also examined, including predicted subcellular localization of the protein and conserved functional domains within each predicted protein. TargetP1.1, SignalP3.0, SignalP4.0, TMHMM2.0, PredGPI, Phobius, Prosite and WoLF PSORT were used to ensure that the predicted sugar transporters are located within the cell membrane. UniProtKB and FunSecKB scores of the closest BLAST hit were used for confirmation when there were contradictions in the prediction and then subcellular localizations were manually curated. Positive indicators of a predicted sugar transporter include conservation of the sugar transporter domain and high numbers of predicted transmembrane helices, which strongly suggest that the protein is located in the plasma membrane.

Once the sugar transporters were identified, several of them were selected for closer study based on Orthofam ID uniqueness, information yielded from National Center for Biotechnology Information (NCBI) BLAST hits against other genomes, and initial expression data already collected through RNASeq, which provides RNA quantity from a genome at a certain point in time, such as a certain stage of the life cycle [6]. The initial expression data (Table 2) were taken from the fungus isolated from three different growth conditions - haploid cells on rich agar, haploid cells on water agar, and late stage infection (i.e., dikaryotic or diploid fungus) in male floral tissue of $S$. 
latifolia.

\section{RNA Purification and Manipulation}

Liquid nitrogen grinding was used to prepare the cells for RNA isolation, which was done using the RNeasy ${ }^{\mathrm{TM}}$ Plus Mini Kit (Qiagen, Venlo). Illumina sequencing was used to analyze gene expression levels in three RNA sequencing experiments, as follows:

Rich: 4-day old yeast-like haploid cells, p1A1 and p1A2 (Fig 1d), grown separately on rich media. Water: 4-day old yeast-like haploid cells, p1 A1 and p1 A2 (Fig 1d), grown separately on rich media, then placed separately on nutrient-free media at $14^{\circ} \mathrm{C}$ for 3 days.

MI late: $4 \mathrm{~mm}$ to fully bloomed, male infected host floral tissue (Fig 1a), containing diploid fungus undergoing teliosporogenesis.

Reverse Transcriptase-Polymerase Chain Reaction (RT-PCR) using Invitrogen ${ }^{\mathrm{TM}}$ SuperScript III First-Strand Synthesis System (Life Technologies) was then performed on the RNA samples extracted from $M$. violaceum grown in the three conditions used for the initial analysis, as well as when mated on water agar. This last condition was another unique aspect of the study, as mating is a prerequisite for pathogenic development; when exposed to a suitable host plant, the mated cells further differentiate into a dikaryotic filamentous form that penetrates the plant [1]. The isolated RNA samples were then DNase-treated (Ambion Turbo DNA-free ${ }^{\mathrm{TM}} \mathrm{Kit}$ ) to remove all traces of DNA from the sample. The reverse transcriptase reaction created cDNA from the RNA. This cDNA product from the reverse transcriptase reaction was then tested for quality and full degradation of genomic DNA (gDNA) using standard PCR and agarose gel electrophoresis. Polymerase Chain Reaction is a reaction that repeatedly and selectively replicates a segment of DNA that is flanked by small DNA primers to allow for replication. The samples were then subjected to an agarose gel by the application of field electrophoresis to verify their size and the absence of contamination by other DNA. 
Quantitative real-time PCR (qPCR) was then performed on each gene for every condition. qPCR is the same reaction as standard PCR, but a dye is added that fluoresces when bound to double-stranded DNA. As more and more double-stranded DNA is made during PCR, this increasing fluorescence is measured and the instrument readings allow the relative expression of various genes to be determined [16]. These experiments utilized SYBR Green dye and the Applied Biosystems StepOne Real-Time PCR system.

MVLG_00180 (beta tubulin) was used as the endogenous control, because it is consistently expressed under all of the growth conditions. The optimal primer $(62.5 \mathrm{nM})$ was determined, and triplicate samples and water negative controls were used for each gene. The cDNA obtained from the haploid strain, p1A1, grown on rich media was used as the reference to which all of the other conditions were compared [4]. $1.6 \mu \mathrm{l}$ of each $2.5 \mu \mathrm{M}$ primer, $6.4 \mu \mathrm{l}$ of cDNA template, $32 \mu \mathrm{l}$ of Power SYBR Green PCR Master Mix (Applied Biosystems), and $32 \mu \mathrm{l}$ of water was used for each triplicate to yield $20 \mu \mathrm{l}$ reactions. The thermal cycling comprised an initial step at $95^{\circ} \mathrm{C}$ for 10 minutes and 40 cycles of $95^{\circ} \mathrm{C}$ for 15 seconds and $60^{\circ} \mathrm{C}$ for 1 minute. The difference in the fluorescence signal between MVLG_00180 and each gene of interest was measured with cDNA prepared from the fungus under each growth condition. This fluorescence difference between each gene and MVLG_00180 was then compared to the same difference in the reference sample (p1A1 rich cDNA). These comparisons show whether the gene is differentially expressed under each growth condition relative to the p1A1 type grown on rich agar [14]. This is known as the comparative CT method of analyzing qPCR data. The equations used to generate the log fold change were $\left(-\operatorname{LOG}\left(1 /\left(2^{\wedge}(-\mathrm{N})\right)\right)\right.$ for positive values and $\left(\operatorname{LOG}\left(2^{\wedge}(-\mathrm{F} 6)\right)\right)$ for negative values. These relative expression data serve as validation of the initial expression data collected through RNASeq and adds data for the mated fungus. 


\section{Transformation of M. violaceum and Over-Expression of Target Genes}

Differential expression of genes between the conditions has prompted ongoing transformation experiments in order to overexpress genes in certain conditions to view morphological and developmental changes. These observations may give insight as to the role of the gene in pathogenicity and/or mating [5].

Overlap PCR was performed for each selected gene to create a construct with the appropriate promoter for the condition, such as overexpression of the gene in the fungus grown on water agar. After viewing the RNASeq data for the respective conditions, candidate promoters were chosen from $M$. violaceum genes that were found to be among the most highly expressed on water agar or on rich media. For amplification of each sugar transporter gene coding sequence fragment, the cycling conditions comprised an initial step at $94^{\circ} \mathrm{C}$ for 4 minutes, followed by 35 cycles of denaturing at $94^{\circ} \mathrm{C}$ for 30 seconds, annealing at $60^{\circ} \mathrm{C}$ for 30 seconds, and extension at $72^{\circ} \mathrm{C}$ for 2 minutes and 10 seconds, followed by a terminal extension at $72^{\circ} \mathrm{C}$ for 5 minutes. The cycling conditions for amplification of the promoter fragment were the same as for the gene coding fragment, but with a 1 minute and 10 second extension rather than a 2 minute and 10 second extension each cycle. For both of these PCR experiments, $1.25 \mu \mathrm{l}$ of the forward and reverse

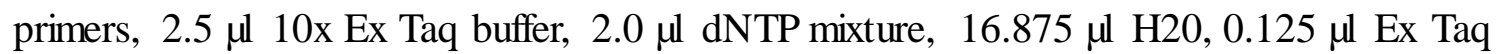
Polymerase (Takara Bio), and $1.0 \mu \mathrm{l}$ of the DNA template (cDNA for coding sequences of genes, gDNA for promoter sequences) were used for each $25 \mu \mathrm{l}$ reaction.

For the overlap PCR reaction, $2.0 \mu \mathrm{l}$ of the forward and reverse primers (table 1), $5.0 \mu \mathrm{l} 10 \mathrm{x}$

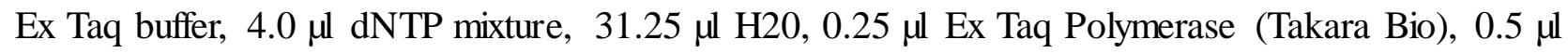
of the promoter fragment DNA template, and $5.0 \mu$ of the gene coding fragment were used for each $50 \mu \mathrm{l}$ reaction. Cycling conditions comprised an initial step at $94^{\circ} \mathrm{C}$ for 4 minutes, followed by 35 cycles of denaturing at $94^{\circ} \mathrm{C}$ for 30 seconds, annealing at $60^{\circ} \mathrm{C}$ for 30 seconds, and extension at $72^{\circ} \mathrm{C}$ for 3 minutes and 30 seconds, followed by a terminal extension at $72^{\circ} \mathrm{C}$ for 5 minutes. All fragments were recovered from agarose gels by using the Zymoclean ${ }^{\mathrm{TM}}$ Gel DNA Recovery Kit. 
These constructs will be inserted into a TOPO TA pCR2.1 vector (Life Technologies) that is optimized for cloning PCR products in E. coli. After identifying clones, the constructs will be subsequently cut out and introduced into similarly digested vector for transformation of $M$.

violaceum. The transformed cells will then be grown under the appropriate conditions and observed. Ideally, some phenotypic change will occur to allow conclusions concerning the function of the gene in development/pathogenicity to be made.

Table 1. Primer sequences used to create coding sequence and promoter fragments for overlap PCR. Primers were designed using Primer3 software.

\begin{tabular}{|l|l|}
\hline \multicolumn{1}{|c|}{ Target } & \multicolumn{1}{c|}{ Primer Sequence } \\
\hline MV05589F & AATTAATTAA|GCTGTATAGGGGGTTCGTGA \\
\hline MV07006F $F_{\text {RC_MV05589R }}$ & TTGTGTAATGATGGCTTGGC|AGAGA GGATGCGATCGA GTG \\
\hline MV05589R_RC_MV07006F & CACTCGATCGCATCCTCTCT|GCCAAGCCATCATTACACAA \\
\hline MV07006R & AAAAGGACGGA GCGA GAAAG \\
\hline MVLG06949F & AATTAATTAA|CCACCCACAGAACAACTCAA \\
\hline MVLG07006FRC_MVLG06949R & TTGTGTAATGATGGCTTGGC|TCTTCA GGGTCGTTCCCTCT \\
\hline MVLG06949RRC_MVLG07006F & AGAGGGAACGACCCTGAAGA|GCCAA GCCATCATTACACAA \\
\hline MVLG00507FRC_MVLG06949R & GCAAGACATGGCCTCTCA|TCTTCA GGGTCGTTCCCTCT \\
\hline MVLG06949RRC_MVLG00507F & AGAGGGAACGACCCTGAAGA|TGA GA GGCCATGTCTTGC \\
\hline MVLG00507R & GAACCACACGCAGACCTAAA \\
\hline
\end{tabular}

\section{$\underline{\text { Results and Discussion }}$}

Initial Bioinformatic Analyses and Target Gene Selection

Of the 64 M. violaceum genes that contain the sugar_tr domain (PF0083), 25 were also BLASTP hits to Srt1 (Genbank: XP_758521) of Ustilago maydis and Hxt1 (Genbank: CAC41332) of Uromyces fabae. Of these 25 predicted sugar transporters, four were up-regulated in MI late. Two were down-regulated in MI late. Two were up-regulated and two down-regulated in Water. One was up-regulated and one down-regulated in Rich. One was upregulated in Water relative to MI late. One was upregulated in Rich relative to MI late, and one was upregulated in Water relative to Rich. Nine were not differentially expressed. Of these 25 that were hits to Srt1 or Hxt1, 7 were selected for additional study based on OrthfamID uniqueness, differential expression in initial 
analysis, and information yielded from BLAST hits to the NCBI database (Table 2, Table 3).

Table 2. Rationale for choosing each gene described in detail.

\begin{tabular}{|c|l|}
\hline \multicolumn{1}{|c|}{$\begin{array}{c}\text { Gene } \\
\text { Name }\end{array}$} & \multicolumn{1}{c|}{ Rationale for Choosing } \\
\hline MVLG_07006 & $\begin{array}{l}\text { Upregulated in MI late. NCBI protein BLAST gives reason to believe it is a maltose permease. Part } \\
\text { of maltose permease family. }\end{array}$ \\
\hline MVLG_05093 & Upregulated in MI late. NCBI protein BLAST gives reason to believe it is a lactose permease. \\
\hline MVLG_04801 & $\begin{array}{l}\text { Unique orthofam ID, localization uncertain. NCBI protein BLAST yield no further information other } \\
\text { than that it is a sugar transporter. }\end{array}$ \\
\hline MVLG_06292 & $\begin{array}{l}\text { Unique orthofam ID. NCBI protein BLAST gives reason to believe it is an iron permease and/or } \\
\text { maybe a multidrug transporter, though it belongs to the sugar transporter family as well. Gene is also } \\
\text { in the fungal trichothecene (myotoxins produced by some fungi, such as some species of Fusarium) } \\
\text { efflux pump family. }\end{array}$ \\
\hline MVLG_06941 & $\begin{array}{l}\text { Downregulated in MI late. NCBI protein BLAST gives reason to believe it is a monosaccharide } \\
\text { transporter, no indication of specificity. }\end{array}$ \\
\hline MVLG_00507 & $\begin{array}{l}\text { Downregulated in MI late. NCBI protein BLAST gives reason to believe it is a phosphate transporter } \\
\text { or permease. Part of phosphate H+ symport family as well as sugar transporter family. }\end{array}$ \\
\hline MVLG_05629 & $\begin{array}{l}\text { Upregulated in water. NCBI protein BLAST yielded no further information other than that it is a sugar } \\
\text { transporter. }\end{array}$ \\
\hline
\end{tabular}

Table 3. Descriptive matrix from RNASeq data showing initial expression data of each gene.

\begin{tabular}{|c|c|c|c|c|c|c|c|}
\hline Gene Name & water.rsem & rich.rsem & milate.rsem & $\begin{array}{c}\text { w_v_r } \\
\text { logFoldChange }\end{array}$ & $\begin{array}{c}\text { w_v_mi } \\
\text { logFoldChange }\end{array}$ & $\begin{array}{c}\text { r_v_mi } \\
\text { logFoldChange }\end{array}$ & Regulation \\
\hline MVLG_07006 & 8 & 10 & 1043 & $\mathrm{~ns}$ & -8.583 & -8.4558 & $\begin{array}{r}\mathrm{Up} \text { in } \mathrm{MI} \\
\text { Late }\end{array}$ \\
\hline MVLG_05093 & 1 & 5 & 615 & $\mathrm{~ns}$ & -10.8209 & -8.6937 & $\begin{array}{r}\text { Up in MI } \\
\text { Late }\end{array}$ \\
\hline MVLG_04801 & 42 & 19 & 19 & $\mathrm{~ns}$ & $\mathrm{~ns}$ & $\mathrm{~ns}$ & $\mathrm{~ns}$ \\
\hline MVLG_06292 & 125 & 56 & 39 & $\mathrm{~ns}$ & $\mathrm{~ns}$ & $\mathrm{~ns}$ & $\mathrm{~ns}$ \\
\hline MVLG_06941 & 1605 & 2075 & 4 & $\mathrm{~ns}$ & 7.09186 & 7.2676 & $\begin{array}{l}\text { Down in } \\
\text { MI Late }\end{array}$ \\
\hline MVLG_00507 & 3841 & 13249 & 91 & $\mathrm{~ns}$ & 3.8429 & 5.4345 & $\begin{array}{l}\text { Down in } \\
\text { MI Late }\end{array}$ \\
\hline MVLG_05629 & 1264 & 166 & 44 & 3.0851 & 3.2878 & $\mathrm{~ns}$ & $\begin{array}{l}\text { Up in } \\
\text { Water }\end{array}$ \\
\hline \multicolumn{8}{|c|}{$\begin{array}{l}\text { Rsem data shows transcript copy number for each gene in each condition. The logFoldChange shows the change in } \\
\text { expression of the gene, if any, between the two conditions. For instance, the w_v_r logFoldChange column compares } \\
\text { expression in water to that in rich. The Regulation column describes the differential expression of the gene, if any, based } \\
\text { on the greatest magnitude logFoldChange. "ns"stands for "Not Significant". }\end{array}$} \\
\hline
\end{tabular}


The inventory of predicted proteins, differentially expressed, provides insights into critical aspects of the unique biotrophic lifestyle of $M$. violaceum. M. violaceum, despite being a biotrophic pathogen, actually causes necrosis in floral tissue, preventing the flower from creating pollen in

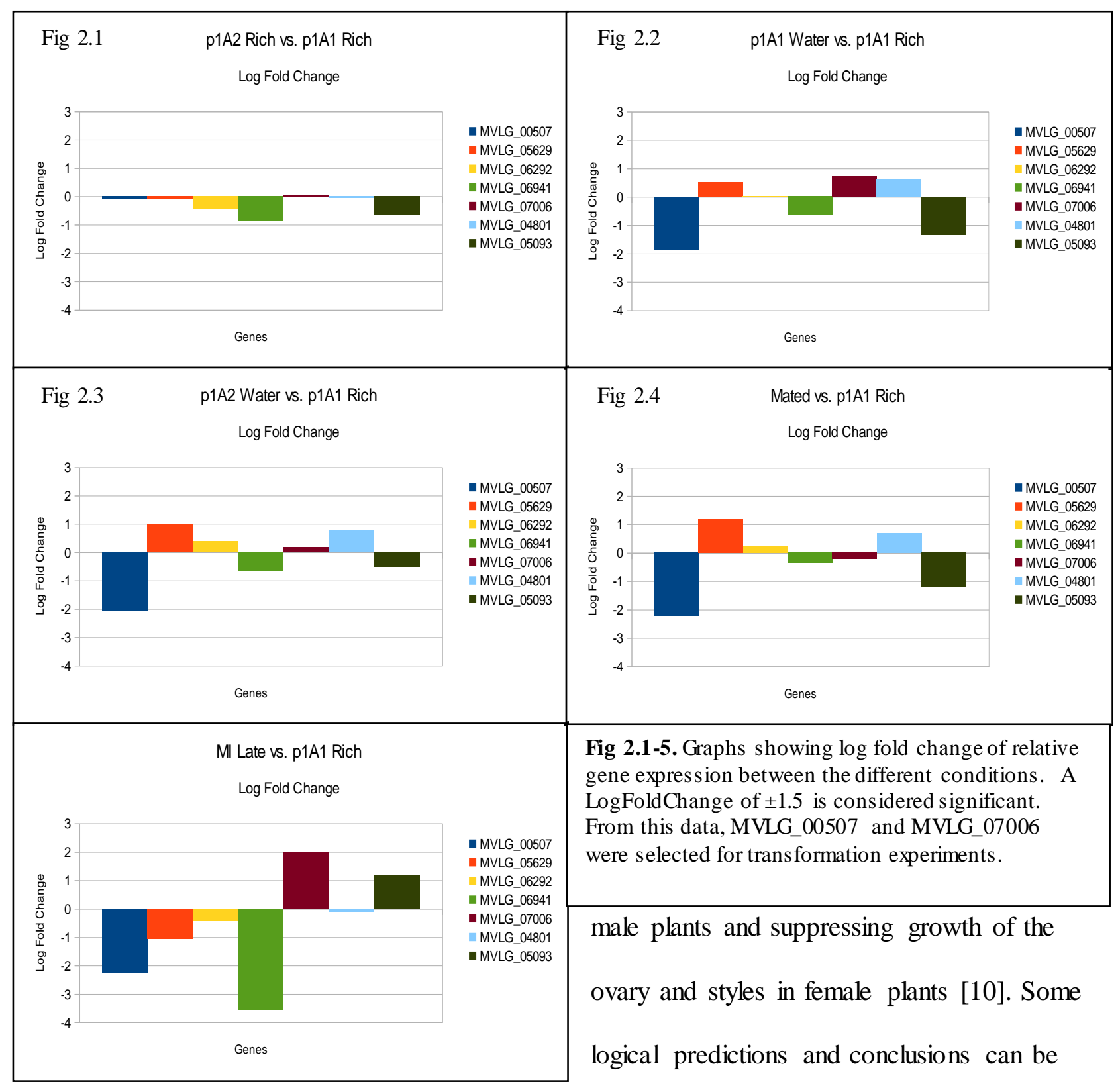

made about sugar transporters that may play a role in this process from the relative expression data gathered (Table 4, Figs 2.1-2.5) [5, 17, 18].

The predicted proteins that are down-regulated in MI late (MVLG_00507, MVLG_06941) may hinder the progression of the fungus into the next stage of its life cycle (teliosporogenesis), may induce a defense mechanism from the host or both $[13,15,18]$. The predicted proteins that are 
up-regulated in MI late may be involved in host invasion and evasion of physical and chemical defense system [9]. It would also make sense that it may scavenge nutrients from the tissue damaged by the fungus $[7,10,19]$. The predicted proteins that are up-regulated in Mated (MVLG_5629) may be necessary for the fungus to mate properly and progress to the next stage of its life-cycle (dikaryon formation). The predicted proteins that are down-regulated in Water (MVLG_05093) may cause problems with cell-cell communication, hindering the mating process [20]. The predicted proteins that are up-regulated in Water (MVLG_06292, MVLG_04801) may possibly be involved in preparation for mating and associated responses to nutrient starvation [3].

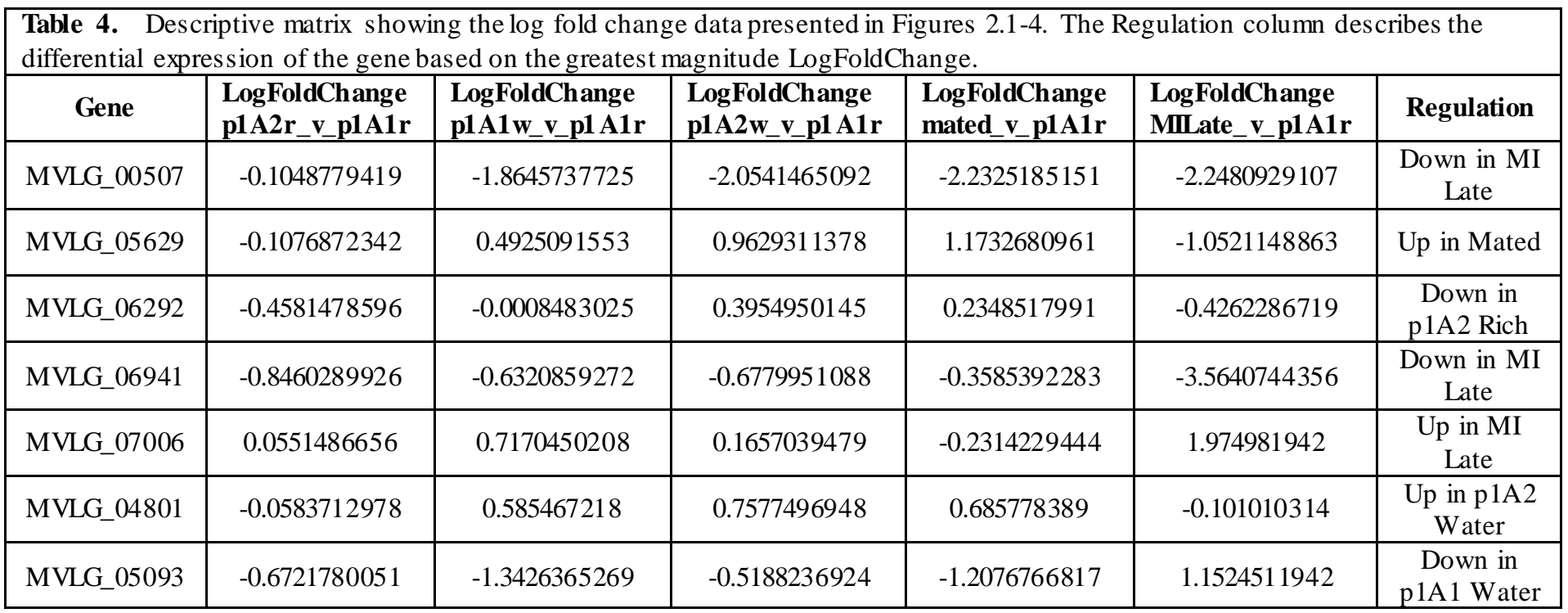

Transformation of $M$. violaceum and Over-Expression of Target Genes

Constructs have been made from promoters of genes that are very highly expressed in the fungus grown in rich (MVLG_05598) or water (MVLG_06949) media and two of the genes that showed the greatest differential expression, MVLG_00507 and MVLG_07006 (Table 4, Figs 2.12.5, 3.1-3.3). As MVLG_07006 is upregulated in MI Late, the effects of upregulating it in water or rich media may show why it is not as highly expressed in earlier stages of development or during mating. Similarly, MVLG_00507 is heavily down regulated in MI Late, mated, and water; upregulating it in those conditions may provide insight as to why it is so upregulated in rich media. 
Attempts to clone the constructs into TOPO vectors and insert them into E.coli are ongoing. Once this is achieved, the constructs will be subcloned into an appropriate vector and used for the transformation of $M$. violaceum. Potential transformants will be confirmed for overexpression of the appropriate gene by qPCR. The transformants will then be assessed for any morphological or developmental changes when grown in the appropriate condition.

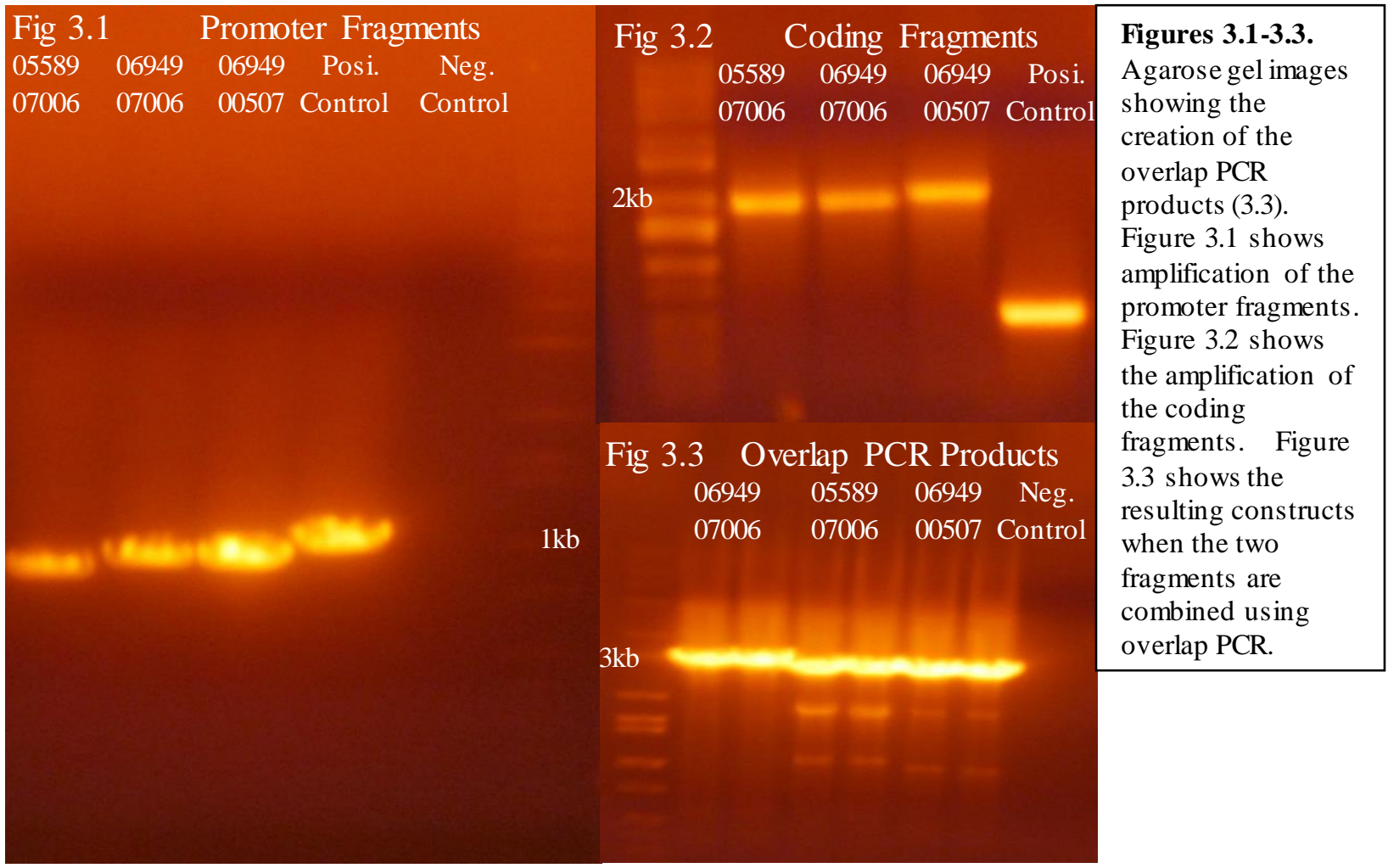

There are a number of predictions that can be made about the experimental outcomes. If a gene is typically downregulated in mated cells (such as MVLG_00507), it seems reasonable that overexpressing the gene in the fungus grown on water agar (a condition that normally promotes mating) may interfere with mating either by a lower frequency of mating or morphological change in cells that hinders mating. Similarly, if a gene that is normally downregulated in fungus grown in rich media is overexpressed, filamentation may be induced or growth accelerated. Conversely, if a gene is normally upregulated in rich media in relation to all other conditions (such as MVLG_07006), it can be hypothesized that the sugar transporter may be specific for the sugar present in the media (glucose in our experiments) or may inhibit mating in some other way or both. Overexpression of this gene on water agar may lead to an inhibition of mating. 


\section{Future Work}

The transformation experiments will direct the next logical to examine the many aspects of sugar transporters in M. violaceum. M. violaceum transformants, especially those with phenotypic changes, will again be characterized for levels of expression or their respective "trans"-gene to make certain that there has indeed been an increase in expression relative to the wild type strains. Additional experiments to look at expression levels during other stages of development within the plant (e.g., directly after infection, earlier stages of bud development, etc.) will provide insight into the role sugar transporters play in earlier stages of infection or evasion of plant defenses. Expression experiments with the fungus grown on media containing different types of sugars may also yield information about the specificity of each sugar transporter and the regulation of their genes, as well as suggesting additional specific roles to be tested in the developmental stages of this fungus. 


\section{References}

1. Alexander HM: An Experimental Field Study of Anther-Smut Disease of Silene alba Caused by Ustilago violacea: Genotypic Variation and Disease Incidence. Evolution 1989, 43(4):835-847.

2. Antonovics J, Hood ME, Partain J: The Ecology and Genetics of a Host Shift: Microbotryum as a Model System. The American Naturalist 2002, 160(S4):S40-S53.

3. Bahn Y-S, Xue C, Idnurm A, Rutherford JC, Heitman J, Cardenas ME: Sensing the environment: lessons from fungi. Nature Reviews Microbiology 2007, 5(1):57-69.

4. Bustin Sxaa, Mueller R: Real-time reverse transcription PCR (qRT-PCR) and its potential use in clinical diagnosis. Clinical Science 2005, 109:365-379.

5. Chen L-Q, Hou B-H, Lalonde S, Takanaga H, Hartung ML, Qu X-Q, Guo W-J, Kim J-G, Underwood W, Chaudhuri B et al: Sugar transporters for intercellular exchange and nutrition of pathogens. Nature 2010, 468(7323):527-532.

6. Chu Y, Corey DR: RNA sequencing: platform selection, experimental design, and data interpretation. Nucleic acid therapeutics 2012, 22(4):271-274.

7. Divon HH, Fluhr R: Nutrition acquisition strategies during fungal infection of plants . FEMS microbiology letters 2007, 266(1):65-74.

8. Hughes CF, Perlin MH: Differential expression of mepA, mepC and smtE during growth and development of Microbotryum violaceum. Mycologia 2005, 97(3):605-611.

9. Idnurm A, Howlett BJ: Pathogenicity genes of phytopathogenic fungi. Molecular Plant Pathology 2001, 2(4):241-255.

10. Mendgen K, Hahn M: Plant infection and the establishment of fungal biotrophy. Trends in Plant Science 2002, 7(8):352-356.

11. Ozcan S, Johnston M: Three different regulatory mechanisms enable yeast hexose transporter (HXT) genes to be induced by different levels of glucose. Molecular and Cellular Biology 1995, 15(3):1564-1572.

12. Özcan S, Johnston M: Function and Regulation of Yeast Hexose Transporters. Microbiology and Molecular Biology Reviews 1999, 63(3):554-569.

13. Rolland F, Baena-Gonzalez E, Sheen J: Sugar sensing and signaling in plants: conserved and novel mechanisms. Annu Rev Plant Biol 2006, 57:675-709.

14. Schmittgen TD, Livak KJ: Analyzing real-time PCR data by the comparative CT method. Nature protocols 2008, 3(6):1101-1108.

15. Sheen J, Zhou L, Jang J-C: Sugars as signaling molecules. Current Opinion in Plant Biology 1999, 2(5):410-418.

16. Udvardi MK, Czechowski T, Scheible W-R: Eleven golden rules of quantitative RT-PCR. The Plant Cell Online 2008, 20(7):1736-1737.

17. Voegele RT, Struck C, Hahn M, Mendgen K: The Role of Haustoria in Sugar Supply during Infection of Broad Bean by the Rust Fungus Uromyces fabae. Proceedings of the National Academy of Sciences of the United States of America 2001, 98(14):8133-8138.

18. Wahl R, Wippel K, Goos S, Kämper J, Sauer N: A Novel High-Affinity Sucrose Transporter Is Required for Virulence of the Plant Pathogen Ustilago maydis. PLoS Biol 2010, 8(2):e1000303.

19. Wieczorke R, Krampe S, Weierstall T, Freidel K, Hollenberg CP, Boles E: Concurrent knock-out of at least 20 transporter genes is required to block uptake of hexoses in Saccharomyces cerevisiae. FEBS Lett 1999, 464(3):123-128.

20. Yoder O, Turgeon BG: Fungal genomics and pathogenicity. Current opinion in plant biology 2001, 4(4):315-321. 